\title{
Penggunaan Rantai Markov Orde Dua untuk Menganalisis Ketersediaan Pemasaran Produk Sampo Z di Swalayan Pamella 1 Yogyakarta
}

\author{
Syarifah INAYATI ${ }^{1}$, NUR MUHaimi \\ ${ }^{1}$ Jurusan Pendidikan Matematika, Fakultas MIPA, Universitas Negeri Yogyakarta \\ Jl. Colombo Nomor 1 Yogyakarta 55281 \\ Email: syarifah.inayati@uny.ac.id
}

\begin{abstract}
Abstrak
Persaingan dunia industri yang semakin pesat saat ini mendorong setiap perusahaan untuk memperhitungkan ketersediaan produk yang akan mereka jual, sehingga dapat meminimalisir kerugian yang akan terjadi. Sampo merupakan salah satu produk kosmetik yang memiliki banyak variasi produk dari segi isi kandungan, manfaat, dan juga ukuran, sehingga dapat terjadi persaingan antar produk itu sendiri. Dalam makalah ini, penulis ingin mengevaluasi ketersediaan pemasaran produk sampo Z di swalayan Pamella 1 Yogyakarta dengan menggunakan rantai Markov orde dua, sehingga tingkat penjualan dapat optimal. Model rantai Markov ini menggunakan nilai saat ini dan sebelumnya untuk menggambarkan tingkat ketersediaan produk pada periode berikutnya. Data diambil dari penjualan produk bulanan pada Januari 2015 sampai dengan Juni 2017. Berdasarkan perhitungan tujuh belas varian produk sampo $\mathrm{Z}$ yang tersedia, produk yang paling menguasai pangsa pasar adalah sampo Z17 dan yang paling tidak diminati adalah sampo Z2. Dapat diprediksi bahwa rata-rata penjualan produk sampo di bulan Juli 2017 akan menurun dari penjualan rata-rata di bulan Juni 2017 hingga 0,06

Kata kunci: ketersediaan sampo, pangsa pasar, rantai Markov.
\end{abstract}

\begin{abstract}
The increasingly rapid competition in the industrial world now encourages every company to take into account the availability of the products they will sell, so as to minimize the losses that will occur. A second-order Markov chain model is used to evaluate the availability of a product that controls market share. This model uses the current and preceding values to describe the level of product availability in the next period. The goal is to optimize the level of product sales. In this paper, the model is applied to evaluate the readiness of marketing of $Z$ shampoo products on Pamella 1 supermarket in Yogyakarta. The data is taken from monthly product sales from January 2015 to June 2017. Based on the calculation of the seventeen variants of $Z$ shampoo products available, the most popular product is Z17 shampoo, and the least desirable is the Z2 shampoo. It can be predicted that the average sales of shampoo products in July 2017 will decrease from the average sales in June 2017 to 0.06

Keywords: the availability of shampoo, market share, Markov chain.
\end{abstract}

2000 Mathematics Subject Classification: 60J10

Received: 2019-02-14, Revisions: 2019-04-06, Accepted: 2019-06-18. 


\section{Pendahuluan}

Rantai Markov adalah proses stokastik yang dapat diukur dengan secara empiris memperkirakan probabilitas transisi pada suatu keadaan diskrit dalam sistem yang diamati (Heiko [1]). Sebagai alat dalam riset operasi untuk pengambilan keputusan manajerial, rantai Markov telah banyak digunakan untuk menganalisis perpindahan merek (brand switching) dalam pemasaran, perhitungan rekening-rekening, jasa-jasa penyewaan mobil, perencanaan penjualan, masalah-masalah persediaan, pemeliharaan mesin, antrian, perubahan harga pasar saham, administrasi rumah sakit, dan sebagainya (Vantika dan Pasaribu [2]).

Dalam penerapannya pada masalah persediaan, rantai Markov telah banyak digunakan untuk melakukan pemodelan bermacam-macam sistem dan proses bisnis. Teknik ini dapat digunakan untuk memprediksi perubahan yang akan terjadi di masa depan berdasarkan beberapa informasi di masa lalu. Semakin pesatnya persaingan dalam dunia industri, mendorong setiap perusahaan untuk mampu bersaing dengan mengedepankan produk berupa barang atau jasa yang ditawarkannya.

Sampo adalah salah satu kosmetik pembersih rambut dan kulit kepala dari segala macam kotoran, baik yang berupa minyak, debu, sel-sel yang sudah mati dan sebagainya (Latifah [3]). Sampo memiliki banyak variasi produk dari segi isi kandungan, manfaat, dan juga ukuran, sehingga dapat terjadi persaingan antar produk itu sendiri. Untuk itu, toko, swalayan atau industri penjual produk ini harus berhati-hati dalam memperhitungkan ketersediaan produkproduk yang akan mereka jual, sehingga dapat meminimalisir kerugian yang akan terjadi.

Dalam penelitian ini model rantai Markov orde dua digunakan untuk mengevaluasi ketersediaan produk yang menguasai pangsa pasar dan ketersediaan sampo Z di Swalayan Pamella 1 Yogyakarta. Hasil evaluasi berupa produk mana yang paling menguasai pangsa pasar dan yang paling tidak menguasai berdasarkan data yang diperoleh, kemudian hasil yang diperoleh juga dapat digunakan untuk memprediksi ketersediaan produk sampo $\mathrm{Z}$ beserta variasinya pada periode bulan berikutnya. Penggunaan model rantai Markov orde dua ini memiliki hasil yang lebih akurat dibandingkan model rantai markov orde satu dalam arti hasil analisis model rantai Markov orde dua lebih mendekati hasil simulasi (Paranchych dan Beaulieu [4]). Hal ini dikarenakan, pada model orde satu pembentukan matriks probabilitas transisi dari keadaan saat ini ke keadaan selanjutnya hanya bergantung pada nilai keadaan saat ini sedangkan pada model rantai markov orde dua menggunakan nilai keadaan saat ini dan sebelumnya untuk menggambarkan keadaan berikutnya. Hasil yang diperoleh diharapkan dapat memberikan informasi dalam upaya pengambilan keputusan agar tingkat penjualan dapat optimal.

\section{RANTAi MARKov}

Rantai Markov adalah penerapan baru dari pemrograman dinamis untuk menyelesaikan suatu proses stokastik yang dapat dijelaskan oleh sejumlah state yang terbatas (Ross [5]). Dalam rantai markov, rangkaian proses kejadian berarti bahwa peluang bersyarat kejadian yang akan datang tergantung pada kejadian sekarang (Shamshad et al. [6]).

Proses stokastik adalah serangkaian variable random $X_{t}$, dengan $t=0,1,2, \ldots n$ merupakan indeks waktu atau deretan. Sebuah proses stokastik memperlihatkan sifat-sifat markov jika $\left(P(X)_{t+1}=j \mid X_{t}=i\right)=\left(P(X)_{t+1}=j \mid X_{t}=i, X_{t-1}=i_{1}, X_{t-2}=i_{2}, \ldots, X_{0}=i_{t}\right)$ untuk setiap $t=0,1,2, \ldots n$ dan setiap deretan $j, i, i_{1}, \ldots, i_{t}$. Dengan kata lain probabilitas kejadian $t+1$ tergantung keadaan pada waktu $t$. Probabilitas bersyaratnya $P\left(X_{t+1}=j \mid X_{t}=i\right)=P_{i j}$ disebut probabilitas transisi 1-langkah dan dikatakan stasioner jika probabilitas transisi yang 
dihitung bebas terhadap peubah waktu $t$. Matriks probabilitas transisi dapat dinotasikan sebagai berikut.

$$
P=\left[\begin{array}{cccc}
P_{00} & P_{01} & \cdots & P_{0 n} \\
P_{10} & P_{11} & \cdots & P_{1 n} \\
\vdots & \vdots & \vdots & \vdots \\
P_{n 0} & P_{n 1} & \cdots & P_{n n}
\end{array}\right]
$$

dengan $\sum_{j=0}^{n} P_{i j}=1$, untuk setiap $i=1,2, \ldots n, P_{i j} \geq 0$ untuk setiap $i, j$ adalah keadaan diskrit. (Shamshad et al., [6]).

Dalam Touama [7], probabilitas state pada waktu $t$ dapat diperkirakan dari frekuensi relatif state $n$, jika $f_{i j}$ adalah jumlah transisi dari keadaan $i$ ke keadaan $j$ dalam urutan data maka kemungkinan maksimum perkiraan probabilitas transisi dapat dirumuskan sebagai berikut.

$$
P_{i j}=\frac{f_{i j}}{\sum_{i=0}^{n} f_{i j}}, j=1,2, \ldots, n
$$
sampo Z

Selanjutnya, penulis akan menggunakan persamaan (1) untuk data penjualan produk

Rantai markov orde pertama adalah rantai markov yang hanya bergantung pada satu nilai sebelumnya. Probabilitas transisi pada orde pertama atau 1-langkah dapat di modelkan sebagai berikut (Paranchych dan Beaulieu [4]).

$$
P\left(X_{t+1}=j \mid X_{t}=1, X_{t-1}=i_{1}, X_{t-2}=i_{2}, \ldots, X_{0}=i_{0}\right)=P\left(X_{t+1}=j \mid X_{t}=i\right)=P_{i j}
$$

dengan distribusi bersyarat $X_{t+1}$, diberikan keadaan-keadaan lampau $X_{0}, X_{1}, \ldots, X_{t-1}$ dan keadaan sekarang $X_{t}$, hanya bergantung pada keadaan sekarang dengan keadaan-keadaan (states) $i_{0}, i_{1}, \ldots, i_{t-1}, i, j$.

Rantai markov orde kedua atau orde tinggi adalah rantai markov yang bergantung pada dua atau lebih nilai yang sebelumnya. Probabilitas transisi pada orde kedua atau 2-langkah dapat di modelkan sebagai berikut (Paranchych dan Beaulieu [4]).

$$
P\left(X_{t+1}=j \mid X_{t}=i, X_{t-1}=i_{2}, \ldots, X_{0}=i_{0}\right)=P\left(X_{t+1}=j \mid X_{t}=i, X_{t-1}=t_{t-1}\right)=P_{i j}
$$

dengan distribusi bersyarat $X_{t+1}$, diberikan keadaan-keadaan lampau $X_{0}, X_{1}, \ldots, X_{t-1}$ dan keadaan sekarang $X_{t}$, hanya bergantung pada keadaan sekarang dengan keadaan-keadaan (states) $i_{0}, i_{1}, \ldots, i_{t-1}, i, j$.

Analisa rantai Markov dapat diterapkan dalam kasus dengan beberapa syarat sebagai berikut: (1) Jumlah peluang transisi untuk suatu keadaan awal dari system sama dengan satu; (2) Peluang-peluang tersebut berlaku untuk semua partisispan dalam system; dan (3) Peluang transisi tidak akan berubah untuk selamanya. Dalam proses Analisis rantai Markov, terdapat tiga prosedur utama untuk dilakukan yaitu: (1) Menyusun matriks peluang transisi, (2) Menghitung peluang suatu kejadian di waktu yang akan datang, dan (3) Menentukan kondisi steady state.

Proses markov akan menuju pada steady state (keseimbangan) artinya setelah proses berjalan selama beberapa periode, probabilitas yang dihasilkan akan bernilai tetap, dan probabilitas ini dinamakan Probabilitas steady state. Menentukan Probabilitas steady state dilakukan dengan menguraikan setiap peluang state tersebut dalam sebuah vektor kolom atau vektor keadaan. Steady state dapat ditentukan dengan probabilitas state awal, vektor state probabilitas berada pada state $j$ setelah $t$-langkah $\left(S(t)=\left[S_{j}(t)\right]\right)$, dengan mencari (Kao $\left.[7]\right)$

$$
S(t)=S(0) . P, t=0,1,2, \ldots, n
$$

dengan $S_{j}(t)=P\left(X_{t}=j \mid S(0)\right)$. Vektor state probabilitas menunjukkan perilaku ketergantungan waktu dari rantai markov di bawah vektor probabilitas state awal $S(0)$, dengan

$$
S(0)=\left[\begin{array}{llll}
P_{0}^{0} & P_{1}^{0} & P_{2}^{0} & P_{3}^{0}
\end{array}\right]
$$

dengan $P_{i}^{0}, i=0,1,2,3$ menyatakan peluang pada state $i$ dalam periode waktu tertentu. 
Selanjutnya, untuk menghitung prediksi ketersediaan barang diwaktu mendatang membutuhkan nilai saat ini dan persentase yang telah dicapai dari naik dan turunnya suatu kejadian dalam kurun waktu tertentu hingga saat ini. Nilai prediksi tersebut dapat dihitung dengan model berikut:

Prediksi barang yang akan datang = banyak barang saat ini + (banyak barang saat

ini $\times$ persentase kenaikan) $-($ banyak barang saat ini $\times$ persentase penurunan $)$

\section{Pemodelan Penjualan Sampo}

Pada penelitian ini, data sekunder yang diambil yaitu data penjualan tujuh belas varian sampo Z yang terjual selama periode dua setengah tahun antara Januari 2015 sampai dengan Juni 2017 di Swalayan Pamella 1, Yogyakarta (data terlampir pada Tabel L1). Daftar produk variasi dari sampo $\mathrm{Z}$ yang akan dianalisis terdapat pada Tabel 1. Data yang diambil berupa data perbulan penjualan produk tersebut.

TABEL 1. Daftar produk variasi sampo Z

\begin{tabular}{cc}
\hline Variasi & Deskripsi \\
\hline Z1 & Sampo Z1 10 ml \\
Z2 & Sampo Z2 320 ml \\
Z3 & Sampo Z3 $70 \mathrm{ml}$ \\
Z4 & Sampo Z4 $70 \mathrm{ml}$ \\
Z5 & Sampo Z5 $10 \mathrm{ml}$ \\
Z6 & Sampo Z6 160 ml \\
Z7 & Sampo Z7 70 ml \\
Z8 & Sampo Z8 170 ml \\
Z9 & Sampo Z9 320 ml \\
Z10 & Sampo Z10 70 ml \\
Z11 & Sampo Z11 160 ml \\
Z12 & Sampo Z12 10 ml \\
Z13 & Sampo Z13 320 ml \\
Z14 & Sampo Z14 70 ml \\
Z15 & Sampo Z15 $160 \mathrm{ml}$ \\
Z16 & Sampo Z16 $320 \mathrm{ml}$ \\
Z17 & Sampo Z17 10 ml \\
\hline
\end{tabular}

Berdasarkan data penjualan produk Sampo Z di swayalan Pamella 1, diperoleh informasi peralihan state $(X)$ yang terjadi setiap bulannya. Hasil data penjualan yang menurun setiap bulannya menjelaskan tentang kehilangan konsumen, sedangkan data penjualan yang meningkat menjelaskan tentang perolehan konsumen terhadap produk tersebut. Perolehan konsumen dan kehilangan konsumen dapat diasumsikan seperti berikut:

$$
X_{t}=\left\{\begin{array}{c}
\text { state } P, \text { untuk Perolehan pada waktu ke } t \\
\text { state } K, \text { untuk Kehilangan pada waktu ke } t
\end{array}\right.
$$

Orde kedua pada rantai markov memperhatikan state saat ini $\left(X_{t}\right)$ dan kemarin $\left(X_{t-1}\right)$ untuk menentukan state besok atau yang akan datang $\left(X_{t+1}\right)$. Nilai 0 menyatakan untuk $\mathrm{P}$ atau perolehan konsumen sedangkan untuk $\mathrm{K}$ atau kehilangan konsumen bernilai 1. Model rantai markov yang digunakan;

$$
P\left(X_{t+1} \mid X_{t}, X_{t-1}, \ldots, X_{1}\right)=P\left(X_{t+1} \mid X_{t}, X_{t-1}\right)
$$


Sehingga dapat diasumsikan

$$
Y_{t}=\left\{\begin{array}{l}
\text { state } 0 X_{t}=0, X_{t-1}=0 \mathrm{PP} \\
\text { state } 1 X_{t}=0, X_{t-1}=1 \mathrm{PK} \\
\text { state } 2 X_{t}=1, X_{t-1}=0 \mathrm{KP} \\
\text { state } 3 X_{t}=1, X_{t-1}=1 \mathrm{KK}
\end{array}\right.
$$

Dengan model rantai markov baru:

$$
P\left(Y_{t+1} \mid Y_{t}, Y_{t-1}\right)=P\left(X_{t+1}, X_{t} \mid X_{t}, X_{t-1}\right)=P\left(Y_{t+1} \mid Y_{t}\right)
$$

Sehingga diperoleh matriks probabilitas transisi sebagai berikut

$$
P=\left[\begin{array}{llll}
P_{00} & P_{01} & P_{02} & P_{03} \\
P_{10} & P_{11} & P_{12} & P_{13} \\
P_{20} & P_{12} & P_{22} & P_{23} \\
P_{30} & P_{13} & P_{32} & P_{33}
\end{array}\right]
$$

dengan probabilitas dari masing-masing elemen dapat diperoleh menggunakan persamaan (9) dan (10).

Selanjutnya akan dijelaskan bagaimana memperoleh matriks probabilitas transisi untuk semua varian sampo yang akan dianalisis serta pembahasannya.

\section{Hasil dan Pembahasan}

4.1. Orde kedua pada matriks probabilitas transisi dan steady state. Berdasarkan data penjualan produk Sampo Z di swayalan Pamella 1, akan dibentuk matriks probabilitas dengan menunjukkan proses peralihan dan menentukan jumlah frekuensi peralihan state $\left(f_{i j}\right)$ dua bulan terakhir untuk menentukan bulan berikutnya seperti berikut. dengan menggunakan

TABEL 2. Jumlah frekuensi peralihan state $\left(f_{i j}\right)$ untuk 17 varian sampo Z pada Januari 2015 sampai dengan Juni 2017

\begin{tabular}{ccccccccccccccccc}
\hline $\mathrm{Zi}$ & $f_{00}$ & $f_{01}$ & $f_{02}$ & $f_{03}$ & $f_{10}$ & $f_{11}$ & $f_{12}$ & $f_{13}$ & $f_{20}$ & $f_{21}$ & $f_{22}$ & $f_{23}$ & $f_{30}$ & $f_{31}$ & $f_{32}$ & $f_{33}$ \\
\hline $\mathrm{Z1}$ & 1 & 0 & 5 & 0 & 1 & 0 & 5 & 0 & 0 & 5 & 0 & 2 & 0 & 6 & 0 & 2 \\
$\mathrm{Z} 2$ & 1 & 0 & 1 & 0 & 5 & 0 & 1 & 0 & 0 & 1 & 0 & 8 & 0 & 4 & 0 & 3 \\
$\mathrm{Z3}$ & 2 & 0 & 3 & 0 & 5 & 0 & 3 & 0 & 0 & 3 & 0 & 6 & 0 & 3 & 0 & 2 \\
$\mathrm{Z} 4$ & 0 & 0 & 2 & 0 & 4 & 0 & 2 & 0 & 0 & 2 & 0 & 7 & 0 & 4 & 0 & 4 \\
$\mathrm{Z5}$ & 1 & 0 & 4 & 0 & 6 & 0 & 4 & 0 & 0 & 4 & 0 & 6 & 0 & 3 & 0 & 0 \\
$\mathrm{Z6}$ & 1 & 0 & 3 & 0 & 6 & 0 & 3 & 0 & 0 & 3 & 0 & 7 & 0 & 3 & 0 & 1 \\
$\mathrm{Z} 7$ & 2 & 0 & 4 & 0 & 7 & 0 & 4 & 0 & 0 & 4 & 0 & 5 & 0 & 2 & 0 & 0 \\
$\mathrm{Z} 8$ & 1 & 0 & 2 & 0 & 4 & 0 & 2 & 0 & 0 & 2 & 0 & 7 & 0 & 5 & 0 & 1 \\
$\mathrm{Z} 9$ & 3 & 0 & 4 & 0 & 4 & 0 & 4 & 0 & 0 & 4 & 0 & 3 & 0 & 3 & 0 & 2 \\
$\mathrm{Z} 10$ & 0 & 0 & 3 & 0 & 6 & 0 & 3 & 0 & 0 & 3 & 0 & 6 & 0 & 4 & 0 & 2 \\
$\mathrm{Z} 11$ & 3 & 0 & 5 & 0 & 4 & 0 & 5 & 0 & 0 & 5 & 0 & 3 & 0 & 3 & 0 & 1 \\
$\mathrm{Z} 12$ & 5 & 0 & 2 & 0 & 2 & 0 & 2 & 0 & 0 & 2 & 0 & 5 & 0 & 5 & 0 & 0 \\
$\mathrm{Z} 13$ & 0 & 0 & 3 & 0 & 5 & 0 & 3 & 0 & 0 & 3 & 0 & 6 & 0 & 4 & 0 & 3 \\
$\mathrm{Z} 14$ & 0 & 0 & 5 & 0 & 8 & 0 & 5 & 0 & 0 & 5 & 0 & 5 & 0 & 1 & 0 & 1 \\
$\mathrm{Z} 15$ & 1 & 0 & 2 & 0 & 4 & 0 & 2 & 0 & 0 & 2 & 0 & 7 & 0 & 4 & 0 & 3 \\
$\mathrm{Z} 16$ & 2 & 0 & 4 & 0 & 3 & 0 & 3 & 0 & 0 & 3 & 0 & 4 & 0 & 4 & 0 & 3 \\
$\mathrm{Z} 17$ & 1 & 0 & 4 & 0 & 5 & 0 & 4 & 0 & 0 & 4 & 0 & 5 & 0 & 3 & 0 & 2 \\
\hline
\end{tabular}

(1), maka diperoleh matriks probabilitas transisi orde kedua untuk setiap varian sampo Z yang setiap elemen matriksnya disajikan pada tabel 3. Setelah diperoleh matriks probabilitas transisi maka akan dicari steady state $S(t)$ pada rantai markov orde kedua. Diketahui matriks probabilitas transisi P dan vektor probabilitas state awal $S(0)=\left[\begin{array}{llll}0.2500 & 0.25000 & 0.25000 & 0.25000\end{array}\right]$, 
TABEL 3. Elemen matriks probabilitas tramsisi $\mathrm{P}$ untuk 17 varian sampo Z

\begin{tabular}{|c|c|c|c|c|c|c|c|c|c|c|c|c|c|c|c|c|}
\hline $\mathrm{Zi}$ & $P_{00}$ & $P_{01}$ & $P_{02}$ & $P_{03}$ & $P_{10}$ & $P_{11}$ & $P_{12}$ & $P_{13}$ & $P_{20}$ & $P_{21}$ & $P_{22}$ & $P_{23}$ & $P_{30}$ & $P_{31}$ & $P_{32}$ & $P_{33}$ \\
\hline Z1 & 0.1667 & 0 & 0.8333 & 0 & 0.1667 & 0 & 0.8333 & 0 & 0 & 0.7143 & 0 & 0.2857 & $\begin{array}{ll}0 & 0.7500\end{array}$ & 0 & 0.2500 & \\
\hline $\mathrm{Z} 2$ & 0.5 & 0 & 0.5 & 0 & 0.5556 & 0 & 0.4444 & 0 & 0 & 0.1111 & 0 & 0.8889 & 0 & 0.5714 & 0 & 0.4286 \\
\hline $\mathrm{Z} 3$ & 0.4 & 0 & 0.6 & 0 & 0.625 & 0 & 0.375 & 0 & 0 & 0.3333 & 0 & 0.6667 & 0 & 0.6 & 0 & 0.4 \\
\hline $\mathrm{Z} 4$ & 0 & 0 & 1 & 0 & 0.5 & 0 & 0.5 & 0 & 0 & 0.2222 & 0 & 0.7778 & 0 & 0.5 & 0 & 0.5 \\
\hline $\mathrm{Z} 5$ & 0.2 & 0 & 0.8 & 0 & 0.6667 & 0 & 0.3333 & 0 & 0 & 0.4 & 0 & 0.6 & 0 & 1 & 0 & 0 \\
\hline $\mathrm{Z} 6$ & 0.25 & 0 & 0.75 & 0 & 0.6667 & 0 & 0.3333 & 0 & 0 & 0.3 & 0 & 0.7 & 0 & 0.75 & 0 & 0.25 \\
\hline $\mathrm{Z} 7$ & 0.3333 & 0 & 0.6667 & 0 & 0.7 & 0 & 0.3 & 0 & 0 & 0.4444 & 0 & 0.5556 & 0 & 1 & 0 & 0 \\
\hline $\mathrm{Z} 8$ & 0.3333 & 0 & 0.6667 & 0 & 0.4444 & 0 & 0.3 & 0 & 0 & 0.2222 & 0 & 0.7778 & 0 & 0.8333 & 0 & 0.1667 \\
\hline Z9 & 0.4286 & 0 & 0.5714 & 0 & 0.5 & 0 & 0.5 & 0 & 0 & 0.5714 & 0 & 0.4286 & 0 & 0.6 & 0 & 0.4 \\
\hline Z10 & 0 & 0 & 1 & 0 & 0.6667 & 0 & 0.3333 & 0 & 0 & 0.3333 & 0 & 0.6667 & 0 & 0.6667 & 0 & 0.3333 \\
\hline Z11 & 0.375 & 0 & 0.625 & 0 & 0.5714 & 0 & 0.4286 & 0 & 0 & 0.625 & 0 & 0.375 & 0 & 0.75 & 0 & 0.25 \\
\hline Z12 & 0.625 & 0 & 0.375 & 0 & 0.2857 & 0 & 0.7143 & 0 & 0 & 0.2857 & 0 & 0.7143 & 0 & 1 & 0 & 0 \\
\hline Z13 & 0 & 0 & 1 & 0 & 0.625 & 0 & 0.375 & 0 & 0 & 0.3333 & 0 & 0.6667 & 0 & 0.5714 & 0 & 0.4286 \\
\hline Z14 & 0 & 0 & 1 & 0 & 0.8 & 0 & 0.2 & 0 & 0 & 0.5 & 0 & 0.5 & 0 & 0.5 & 0 & 0.5 \\
\hline Z15 & 0.3333 & 0 & 0.6667 & 0 & 0.5 & 0 & 0.5 & 0 & 0 & 0.2222 & 0 & 0.7778 & 0 & 0.5714 & 0 & 0.4286 \\
\hline Z16 & 0.3333 & 0 & 0.6667 & 0 & 0.4286 & 0 & 0.5714 & 0 & 0 & 0.4286 & 0 & 0.5714 & 0 & 0.5714 & 0 & 0.4286 \\
\hline Z17 & 0.2 & 0 & 0.8 & 0 & 0.625 & 0 & 0.375 & 0 & 0 & 0.4444 & 0 & 0.5556 & 0 & 0.6 & 0 & 0.4 \\
\hline
\end{tabular}

kemudian untuk menghitung probabilitas steady state pada masing-masing varian produk sampo menggunakan persamaan (4). Perhitungan ini akan berlangsung secara iteratif untuk periode ke- $t$ dan akan mencapai keadaan steady state setelah probabilitas yang dihasilkan akan bernilai tetap. Hasil dari perhitungan ini akan lebih mudah diperoleh dengan menggunakan program matlab. Hasil perhitungan disajikan pada tabel 4. Diperoleh hasil bahwa

TABEL 4. Elemen matriks probabilitas steady state untuk 17 varian sampo Z

\begin{tabular}{ccccc}
\hline $\mathrm{Zi}$ & $P_{0}^{n}$ & $P_{1}^{n}$ & $P_{2}^{n}$ & $P_{3}^{n}$ \\
\hline $\mathrm{Z1}$ & 0.0775 & 0.3875 & 0.3875 & 0.1476 \\
$\mathrm{Z} 2$ & 0.2381 & 0.2143 & 0.2143 & 0.3330 \\
$\mathrm{Z3}$ & 0.2508 & 0.2408 & 0.2408 & 0.2676 \\
$\mathrm{Z} 4$ & 0.1233 & 0.2466 & 0.2466 & 0.3836 \\
$\mathrm{Z5}$ & 0.2427 & 0.2913 & 0.2913 & 0.1748 \\
$\mathrm{Z} 6$ & 0.2326 & 0.2616 & 0.2616 & 0.2442 \\
$\mathrm{Z7}$ & 0.2912 & 0.2773 & 0.2773 & 0.1541 \\
$\mathrm{Z} 8$ & 0.1852 & 0.2778 & 0.2778 & 0.2593 \\
$\mathrm{Z9}$ & 0.2438 & 0.2786 & 0.2786 & 0.1990 \\
$\mathrm{Z} 10$ & 0.1818 & 0.2727 & 0.2727 & 0.2727 \\
$\mathrm{Z} 11$ & 0.2678 & 0.2929 & 0.2929 & 0.1464 \\
$\mathrm{Z12}$ & 0.2192 & 0.2877 & 0.2877 & 0.2055 \\
$\mathrm{Z} 13$ & 0.1648 & 0.2637 & 0.2637 & 0.3077 \\
$\mathrm{Z} 14$ & 0.2000 & 0.2750 & 0.2500 & 0.2750 \\
$\mathrm{Z} 15$ & 0.1824 & 0.2432 & 0.2432 & 0.3311 \\
$\mathrm{Z} 16$ & 0.1765 & 0.2745 & 0.2745 & 0.2745 \\
$\mathrm{Z} 17$ & 0.2107 & 0.2697 & 0.2697 & 0.2498 \\
\hline
\end{tabular}

dari setiap varian sampo mencapai keadaan steady state $S(n)=\left[P_{0}^{n}, P_{1}^{n}, P_{2}^{n}, P_{3}^{n}\right]$, sehingga diperoleh jumlah kejadian perpindahan pada kondisi yang stabil untuk masing-masing varian sebagai berikut disajikan pada tabel 5 .

4.2. Pasang pasar produk sampo Z. Pangsa pasar dapat ditentukan dari perolehan jumlah kejadian perpindahan di kondisi yang stabil pada orde kedua sebelumnya. Diketahui persamaan (9). Sehingga dapat dibentuk kembali ke persamaan

$$
X_{t}=\left\{\begin{array}{c}
\text { state } 0 \text { untuk Perolehan P pada waktu ke } t \\
\text { state } 1 \text { untuk Kehilangan P pada waktu ke } t
\end{array}\right.
$$


TABEL 5. Jumlah kejadian perpindahan di kondisi yang stabil pada orde kedua untuk 17 varian

\begin{tabular}{ccccc}
\hline $\mathrm{Zi}$ & $f_{00}$ & $f_{01}$ & $f_{10}$ & $f_{11}$ \\
\hline $\mathrm{Z1}$ & 2 & 10 & 10 & 4 \\
$\mathrm{Z} 2$ & 6 & 6 & 6 & 9 \\
$\mathrm{Z} 3$ & 7 & 7 & 7 & 7 \\
$\mathrm{Z} 4$ & 3 & 7 & 7 & 10 \\
$\mathrm{Z} 5$ & 7 & 8 & 8 & 10 \\
$\mathrm{Z} 6$ & 6 & 7 & 7 & 7 \\
$\mathrm{Z} 7$ & 8 & 7 & 7 & 4 \\
$\mathrm{Z} 8$ & 5 & 7 & 7 & 7 \\
$\mathrm{Z} 9$ & 7 & 8 & 8 & 5 \\
$\mathrm{Z} 10$ & 5 & 7 & 7 & 7 \\
$\mathrm{Z} 11$ & 7 & 8 & 8 & 4 \\
$\mathrm{Z} 12$ & 6 & 8 & 8 & 6 \\
$\mathrm{Z} 13$ & 4 & 7 & 7 & 8 \\
$\mathrm{Z} 14$ & 6 & 7 & 7 & 7 \\
$\mathrm{Z} 15$ & 5 & 7 & 7 & 9 \\
$\mathrm{Z} 16$ & 5 & 7 & 7 & 7 \\
$\mathrm{Z} 17$ & 6 & 7 & 7 & 7 \\
\hline
\end{tabular}

Sehingga akan dibentuk matiks probabilitas transisi yang baru;

$$
P=\left[\begin{array}{ll}
P_{00} & P_{01} \\
P_{10} & P_{11}
\end{array}\right]=\left[\begin{array}{ll}
\frac{P P}{P P+P K} & \frac{P K}{P P+P K} \\
\frac{K P}{K P+K K} & \frac{K K}{K P+K K}
\end{array}\right]
$$

Setelah diketahui matriks probabilitas transisi yang baru dapat ditentukan keadaan stasioner pada penjualan produk sampo Z dengan vektor probabilitas awal proses $S(0)$. Probabilitas state awal yaitu:

$$
S(0)=\left[P_{0}^{0}, P_{1}^{0}\right]
$$

Dengan nilai probabilitas $P_{0}^{0}$ diperoleh dari jumlah kondisi perolehan konsumen $\mathrm{P}$, dibagi dengan jumlah kejadian perpindahan konsumen dan $P_{1}^{0}$ diperoleh dari jumlah kondisi kehilangan konsumen $\mathrm{K}$, dibagi dengan jumlah kejadian perpindahan konsumen tersebut.

Dari data jumlah kejadian perpindahan di kondisi yang stabil pada orde kedua pada tabel 5 diperoleh matriks probabilitas transisi baru yang disajikan pada tabel 6 . Dengan menggunakan cara yang sama dengan mencari probabilitas steady state $S(t)$, apabila diperoleh probabilitas steady state $S(t)$ maka didapatkan kondisi yang stasioner dari perolehan dan kehilangan konsumen sebesar

$$
S(n)=\left[P_{0}^{n}, P_{1}^{n}\right]
$$

dengan setiap elemen matriks dapat disajikan pada tabel 7 
TABEL 6. Elemen matriks probabilitas transisi yang baru untuk 17 varian sampo Z

\begin{tabular}{ccccc}
\hline $\mathrm{Zi}$ & $P_{00}$ & $P_{01}$ & $P_{10}$ & $P_{11}$ \\
\hline $\mathrm{Z1}$ & 0.1667 & 0.8333 & 0.7143 & 0.2857 \\
$\mathrm{Z} 2$ & 0.5000 & 0.5000 & 0.4000 & 0.6000 \\
$\mathrm{Z} 3$ & 0.5000 & 0.5000 & 0.5000 & 0.5000 \\
$\mathrm{Z} 4$ & 0.3000 & 0.7000 & 0.4118 & 0.5882 \\
$\mathrm{Z} 5$ & 0.4667 & 0.5333 & 0.6154 & 0.3846 \\
$\mathrm{Z} 6$ & 0.4615 & 0.5385 & 0.5000 & 0.5000 \\
$\mathrm{Z} 7$ & 0.5333 & 0.4667 & 0.6364 & 0.3636 \\
$\mathrm{Z} 8$ & 0.4267 & 0.5833 & 0.5000 & 0.5000 \\
$\mathrm{Z} 9$ & 0.4667 & 0.5333 & 0.6154 & 0.3846 \\
$\mathrm{Z} 10$ & 0.4167 & 0.5833 & 0.5000 & 0.5000 \\
$\mathrm{Z} 11$ & 0.4667 & 0.5333 & 0.6667 & 0.3333 \\
$\mathrm{Z} 12$ & 0.4286 & 0.5714 & 0.5714 & 0.4286 \\
$\mathrm{Z} 13$ & 03636 & 0.6364 & 0.4667 & 0.5333 \\
$\mathrm{Z} 14$ & 0.4615 & 0.5385 & 0.5000 & 0.5000 \\
$\mathrm{Z} 16$ & 0.4167 & 0.5833 & 0.4375 & 0.5625 \\
$\mathrm{Z} 16$ & 0.4167 & 0.5833 & 0.5000 & 0.5000 \\
$\mathrm{Z} 17$ & 0.4615 & 0.5385 & 0.5000 & 0.5000 \\
\hline
\end{tabular}

TABEL 7. Elemen matriks probabilitas steady state untuk 17 varian sampo Z

\begin{tabular}{ccc}
\hline $\mathrm{Zi}$ & $P_{0}^{n}$ & $P_{1}^{n}$ \\
\hline $\mathrm{Z} 1$ & 0.4615 & 0.5385 \\
$\mathrm{Z} 2$ & 0.4444 & 0.5556 \\
$\mathrm{Z} 3$ & 0.5000 & 0.5000 \\
$\mathrm{Z} 4$ & 0.3704 & 0.6296 \\
$\mathrm{Z} 5$ & 0.5357 & 0.4643 \\
$\mathrm{Z} 6$ & 0.4815 & 0.5185 \\
$\mathrm{Z} 7$ & 0.5769 & 0.4231 \\
$\mathrm{Z} 8$ & 0.4615 & 0.5385 \\
$\mathrm{Z} 9$ & 0.5357 & 0.4643 \\
$\mathrm{Z} 10$ & 0.4615 & 0.5385 \\
$\mathrm{Z} 11$ & 0.5556 & 0.4444 \\
$\mathrm{Z} 12$ & 0.5000 & 0.5000 \\
$\mathrm{Z} 13$ & 0.4231 & 0.5769 \\
$\mathrm{Z} 14$ & 0.4815 & 0.5185 \\
$\mathrm{Z} 15$ & 0.4286 & 0.5714 \\
$\mathrm{Z} 16$ & 0.4615 & 0.5385 \\
$\mathrm{Z} 17$ & 0.4815 & 0.5185 \\
\hline
\end{tabular}


4.3. Menghitung hasil prediksi \& persentase ketersediaan produk yang akan datang. Berdasarkan dari hasil pangsa pasar dengan metode Rantai Markov dua setengah tahun terakhir dari Januari 2015 sampai dengan Juni 2017 pada 17 produk sampo Z, berdasarkan (6) maka didapat prediksi penjualan produk hampoo, yaitu;

Prediksi Penjualan Juli $2017=$ Penjualan Juni $2017+($ Penjualan Juni $2017 \times$ perolehan $)$

-(Penjualan Juni $2017 \times$ kehilangan $)$

Sehingga untuk setiap penjualan variannya disajikan pada tabel 8 .

TABEL 8. Hasil prediksi ketersediaan produk sampo Z

\begin{tabular}{|c|c|c|c|c|c|c|c|}
\hline \multirow[t]{2}{*}{ No. } & \multirow[t]{2}{*}{ Variasi } & \multicolumn{2}{|c|}{$\begin{array}{l}\text { Persentase peralihan } \\
\text { produk dari Januari } \\
\text { 2015-Juni } 2017\end{array}$} & \multirow[t]{2}{*}{$\begin{array}{l}\text { Penjualan } \\
\text { Juni } 2017 \\
\quad \text { (pcs) }\end{array}$} & \multirow{2}{*}{$\begin{array}{l}\text { Prediksi } \\
\text { penjualan } \\
\text { Juli } 2017 \\
\text { (pcs) }\end{array}$} & \multirow{2}{*}{$\begin{array}{c}\text { Presentase } \\
\text { persediaan } \\
\text { Juni } 2017 \\
(\%)\end{array}$} & \multirow{2}{*}{$\begin{array}{c}\text { Prediksi } \\
\text { persediaan } \\
\text { Juli } 2017 \\
2017(\%)\end{array}$} \\
\hline & & Perolehan & Kehilangan & & & & \\
\hline 1 & Z1 & $46.15 \%$ & $53.85 \%$ & 1044 & 964 & 12.13 & 12.99 \\
\hline 2 & $\mathrm{Z} 2$ & $44.44 \%$ & $55.56 \%$ & 7 & 6 & 0.08 & 0.09 \\
\hline 3 & $\mathrm{Z} 3$ & $50.00 \%$ & $50.00 \%$ & 27 & 27 & 0.34 & 0.34 \\
\hline 4 & $\mathrm{Z} 4$ & $37.04 \%$ & $62.96 \%$ & 41 & 30 & 0.38 & 0.51 \\
\hline 5 & $\mathrm{Z} 5$ & $53.57 \%$ & $46.43 \%$ & 1580 & 1693 & 21.30 & 19.65 \\
\hline 6 & $\mathrm{Z} 6$ & $48.15 \%$ & $51.85 \%$ & 40 & 39 & 0.48 & 0.50 \\
\hline 7 & $\mathrm{Z7}$ & $57.69 \%$ & $42.31 \%$ & 58 & 67 & 0.84 & 0.72 \\
\hline 8 & $\mathrm{Z} 8$ & $46.15 \%$ & $53.85 \%$ & 12 & 11 & 0.14 & 0.15 \\
\hline 9 & $\mathrm{Z9}$ & $53.57 \%$ & $46.43 \%$ & 8 & 9 & 0.11 & 0.10 \\
\hline 10 & $\mathrm{Z} 10$ & $46.15 \%$ & $53.85 \%$ & 27 & 25 & 0.31 & 0.34 \\
\hline 11 & Z11 & $55.56 \%$ & $44.44 \%$ & 45 & 50 & 0.63 & 0.56 \\
\hline 12 & $\mathrm{Z} 12$ & $50.00 \%$ & $50.00 \%$ & 2085 & 2085 & 26.24 & 25.94 \\
\hline 13 & Z13 & $42.31 \%$ & $57.69 \%$ & 8 & 7 & 0.09 & 0.10 \\
\hline 14 & Z14 & $48.15 \%$ & $51.85 \%$ & 27 & 26 & 0.33 & 0.34 \\
\hline 15 & Z15 & $42.86 \%$ & $57.14 \%$ & 80 & 69 & 0.86 & 1.00 \\
\hline 16 & Z16 & $46.15 \%$ & $53.85 \%$ & 16 & 15 & 0.19 & 0.20 \\
\hline 17 & $\mathrm{Z} 17$ & $48.15 \%$ & $51.85 \%$ & 2934 & 2825 & 35.56 & 36.50 \\
\hline \multicolumn{2}{|c|}{ Jumlah } & & & 8039 & 7947 & $100 \%$ & $100 \%$ \\
\hline \multicolumn{2}{|c|}{ Rata-rata } & & & 472,88 & 467,45 & & \\
\hline \multicolumn{4}{|c|}{ Persentase rata-rata penjualan } & $4,73 \%$ & $4,67 \%$ & & \\
\hline
\end{tabular}

Tabel 8 menunjukkan bahwa, berdasarkan data penjualan produk sampo Z dalam kurun waktu dua setengah tahun di atas, dari ketujuh belas varian produk sampo Z, produk yang paling menguasai pangsa pasar adalah produk sampo Z17 dan yang paling tidak diminati adalah produk sampo $Z_{2}$. Dilihat dari persediaan produk yang akan datang (pada periode berikutnya) di bulan Juli 2017 akan menurun dari rata-rata penjualan Juni 2017 hingga 0.06\%. Dengan prediksi pergeseran konsumsi masing-masing merek sampo dikalangan pelanggan swalayan Pamella 1 sebagai akibat perpindahan merek sampo pada periode berikutnya adalah produk Z1 menurun hingga 0.86\%, Z2 menurun 0.01\%, Z3 tetap, Z4 menurun $0.13 \%$, Z5 meningkat 1.65\%, Z6 menurun 0.02\%, Z7 meningkat 0.12\%, Z8 menurun 0.01\%, Z9 meningkat 0.01\%, Z10 menurun 0.03\%, Z11 meningkat 0.07, Z12 meningkat 0.3\%, Z13 menurun 0.01\%, Z14 menurun $0.01 \%$, Z15 menurun $0.14 \%$, Z16 menurun $0.01 \%$, dan Z17 menurun $0.94 \%$.

\section{Simpulan}

Berdasarkan hasil penelitian dan pembahasan sebelumnya diperoleh kesimpulan sebagai berikut: 
- Berdasarkan perhitungan tujuh belas varian produk sampo Z yang tersedia, produk yang paling menguasai pangsa pasar adalah produk sampo Z17 dan yang paling tidak diminati adalah produk sampo Z2.

- Berdasarkan data penjualan produk sampo Z dalam kurun waktu dua setengah tahun terakhir, dapat diprediksi bahwa persediaan produk di bulan Juli 2017 akan menurun dari rata-rata penjualan Juni 2017 hingga 0.06\%. Dengan prediksi pergeseran konsumsi masing-masing merek sampo dikalangan pelanggan swalayan Pamella 1 sebagai akibat perpindahan merek sampo pada periode berikutnya yaitu produk Z5, Z7, Z9, Z11, dan Z12 mengalami peningkatan, produk Z1, Z2, Z4, Z6, Z8, Z10, Z13, Z14, Z15, Z16 dan Z17 mengalami penurunan, sedangkan produk Z3 tetap.

\section{DAFtar Pustaka}

[1] Heiko, B., 2000, Markov chain model for vegetation dynamics, Ecological Modeling, 126: 139-154.

[2] Vantika, S., dan Pasaribu, U.S., 2015, Markov Chain for Estimating Human Mitochondrial DNA Mutation Pattern, AIP Conference Proceedings 1692, 020010 (2015).

[3] Latifah, F., 2007, Buku Pegangan Ilmu Pengetahuan Kosmetik, Gramedia Pustaka Utama, Jakarta.

[4] Paranchych, D.W., dan Beaulieu, N.C., 1996, Use of Second Order Markov Chains to model digital symbol synchronizer performance, IEE Proc.-Commun., Vol. 143, No. 5, Octoher 1996.

[5] Ross, S.M., 1996, Stochastic Processes, New York, John Wiley and Sons.

[6] Shamshad, A., Bawadi, M.A., Wan Hussin, W.M.A., Majid, T.A., Sanusi, S.A.M., 2005, First and second order Markov chain models for synthetic generation of wind speed time series, Energy 30 (2005) 693-708.

[7] Touama, H. Y., 2015, Application of Markovian Models and Transition Propbabilities' Matrix To Analyze the Workforce Movement in Jordanian Productivity Companies, Paripex-Indian Journal of Research Volume 4, Issue 6, June 2015, Pages 215-218.

[8] Kao, E. P., 1997, An Introduction to Stochastic Processes, United States of America, Duxbury Press. 


\section{LAMPIRAN}

Tabel 9. Penjualan Produk Shampoo Z dari Januari 2015 sampai dengan Juni 2017 di Swalayan Pamella 1 Yogyakarta

\begin{tabular}{|c|c|c|c|c|c|c|c|c|c|c|c|c|c|c|c|c|c|c|}
\hline \multicolumn{2}{|r|}{ Variasi } & $\mathrm{Z1}$ & $\mathrm{Z} 2$ & $\mathrm{Z3}$ & $\mathrm{Z} 4$ & $\mathrm{Z} 5$ & $\mathrm{Z} 6$ & $\mathrm{Z7}$ & $\mathrm{Z} 8$ & $\mathrm{Z9}$ & $\mathrm{Z} 10$ & Z11 & $\mathrm{Z} 12$ & Z13 & Z14 & Z15 & Z16 & Z17 \\
\hline & \begin{tabular}{|l|l|} 
& Jan-15 \\
\end{tabular} & 912 & 9 & 33 & 67 & 1537 & 72 & 66 & 21 & 10 & 49 & 56 & 1184 & 24 & 48 & 117 & 4 & 1646 \\
\hline & Feb-15 & 898 & 11 & 26 & 41 & 1410 & 70 & 70 & 22 & 11 & 45 & 49 & 1204 & 17 & 41 & 99 & 6 & 1494 \\
\hline & Mar-15 & 876 & 4 & 33 & 45 & 1513 & 94 & 69 & 18 & 2 & 35 & 63 & 1434 & 11 & 48 & 110 & 20 & 1794 \\
\hline & Apr-15 & 949 & 11 & 28 & 53 & 1494 & 69 & 76 & 17 & 5 & 50 & 64 & 1536 & 8 & 53 & 128 & 18 & 1962 \\
\hline & May-15 & 1104 & 10 & 32 & 40 & 1308 & 74 & 85 & 20 & 8 & 40 & 76 & 1512 & 10 & 45 & 141 & 13 & 1875 \\
\hline & Jun-15 & 741 & 7 & 38 & 37 & 1406 & 74 & 59 & 24 & 1 & 33 & 60 & 1234 & 12 & 48 & 100 & 12 & 1524 \\
\hline & Jul-15 & 679 & 9 & 17 & 35 & 1314 & 75 & 58 & 10 & 7 & 25 & 46 & 1251 & 8 & 41 & 80 & 10 & 1383 \\
\hline & Aug-15 & 858 & 8 & 29 & 91 & 1243 & 95 & 109 & 30 & 4 & 40 & 75 & 1129 & 14 & 45 & 152 & 20 & 1627 \\
\hline & Sep-15 & 1242 & 6 & 22 & 48 & 6420 & 94 & 153 & 28 & 2 & 28 & 78 & 1416 & 13 & 89 & 144 & 19 & 1441 \\
\hline & Oct-15 & 1092 & 4 & 33 & 46 & 1320 & 107 & 70 & 28 & & 29 & 85 & 1500 & 18 & 51 & 153 & 23 & 2178 \\
\hline & Nov-15 & 1009 & 13 & 32 & 93 & 1344 & 76 & 102 & 14 & 1 & 39 & 85 & 1568 & 13 & 91 & 108 & 17 & 2162 \\
\hline & Dec-15 & 1352 & 13 & 19 & 48 & 1904 & 70 & 62 & 21 & 10 & 29 & 66 & 1710 & 11 & 38 & 91 & 18 & 2085 \\
\hline$\widetilde{\sigma}$ & Jan-16 & 1095 & 4 & 37 & 42 & 1392 & 75 & 76 & 26 & 16 & 49 & 70 & 1794 & 13 & 48 & 114 & 24 & 2081 \\
\hline & Feb-16 & 426 & 17 & 38 & 52 & 396 & 88 & 69 & 31 & 17 & 45 & 71 & 1748 & 13 & 60 & 94 & 23 & 2530 \\
\hline$\xi$ & Mar-16 & 988 & 13 & 34 & 50 & 1272 & 103 & 74 & 29 & 15 & 51 & 74 & 1684 & 9 & 39 & 135 & 22 & 2490 \\
\hline$\ddot{y}$ & Apr-16 & 1186 & 18 & 34 & 53 & 1653 & 99 & 76 & 36 & 1 & 38 & 57 & 1802 & 20 & 40 & 129 & 17 & 2473 \\
\hline & May-16 & 1255 & 14 & 37 & 42 & 1524 & 57 & 85 & 29 & 9 & 34 & 61 & 1526 & 16 & 41 & 115 & 22 & 2554 \\
\hline & Jun-16 & 1015 & 18 & 32 & 51 & 1542 & 51 & 80 & 22 & 15 & 41 & 47 & 1220 & 10 & 41 & 99 & 17 & 1771 \\
\hline & Jul-16 & 800 & 6 & 45 & 55 & 697 & 64 & 107 & 26 & 17 & 8 & 52 & 2093 & 9 & 53 & 117 & 20 & 2697 \\
\hline & Aug-16 & 588 & 12 & 38 & 48 & 1554 & 55 & 83 & 17 & 8 & 22 & 35 & 1462 & 9 & 34 & 101 & 24 & 1855 \\
\hline & Sep-16 & 997 & 17 & 62 & 80 & 1508 & 61 & 103 & 25 & 16 & 45 & 41 & 1326 & 13 & 50 & 134 & 25 & 2325 \\
\hline & Oct-16 & 1115 & 22 & 56 & 76 & 1761 & 58 & 107 & 20 & 19 & 38 & 73 & 1346 & 16 & 47 & 130 & 46 & 2513 \\
\hline & Nov-16 & 943 & 11 & 50 & 67 & 1664 & 54 & 112 & 15 & 19 & 43 & 57 & 1344 & 14 & 40 & 117 & 41 & 2609 \\
\hline & Dec-16 & 1170 & 14 & 27 & 56 & 1672 & 67 & 83 & 23 & 26 & 48 & 55 & 1254 & 17 & 41 & 115 & 25 & 2295 \\
\hline & Jan-17 & 1043 & 12 & 17 & 46 & 1762 & 57 & 78 & 18 & 12 & 41 & 49 & 1462 & 12 & 47 & 84 & 33 & 2432 \\
\hline & Feb-17 & 934 & 10 & 23 & 44 & 1594 & 59 & 153 & 16 & 7 & 37 & 62 & 1375 & 13 & 33 & 100 & 37 & 2561 \\
\hline & Mar-17 & 878 & 10 & 25 & 58 & 1854 & 84 & 53 & 30 & 19 & 32 & 73 & 1385 & 13 & 37 & 119 & 35 & 2455 \\
\hline & Apr-17 & 976 & 10 & 32 & 48 & 1900 & 74 & 67 & 17 & 16 & 38 & 67 & 1733 & 14 & 36 & 113 & 19 & 2549 \\
\hline & Мay-17 & 1246 & 19 & 36 & 69 & 2323 & 77 & 63 & 18 & 15 & 25 & 71 & 2166 & 19 & 33 & 131 & 27 & 2982 \\
\hline & Jun-17 & 1044 & 7 & 27 & 41 & 1580 & 40 & 58 & 12 & 8 & 27 & 45 & 2085 & 8 & 27 & 80 & 16 & 2934 \\
\hline
\end{tabular}


